\title{
《短 報》
}

\section{人工股関節置換術における股関節外転筋・内転筋力と トレンデレンブルグ徵候との関係}

\author{
薩 摩 博*1 福田寛二*1 寺田勝彦*2 田中清介*1

\section{Muscle Strength and Trendelenburg Sign after Total Hip Arthroplasty}

\author{
Hiroshi Satsuma, ${ }^{* 1}$ Kanji Fukuda, ${ }^{* 1}$ Katsuhiko Terada, ${ }^{* 2}$ Seisuke Tanaka ${ }^{* 1}$
}

\begin{abstract}
Despite the rehabilitative emphasis on hip abductor strength following total hip arthroplasty, it is unclear how muscular strength is related to Trendelenburg sign. Twenty-four patients (mean age 59 years) completed hip abductor and adductor strength assessments at 8 weeks after surgery. Isokinetic force-velocity curve indicated the significantly increased maximum torque for adductor in case of Trendelenburg positive patients. These data shows that hip abductor should play the most important role in Trendelenburg sign, besides it suggests that this sign should have something to do with its balance with hip adductor and force acting on the femoral head. (Jpn J Rehabil Med 1999 ; $36: 234-236$ )
\end{abstract}

要 旨: 変形性股関節症と診断され, 人工股関節置換術を施行した 24 例を対象とした。術 前・術後の X 線像より股関節テコ比を計測し, 術後の股関節外転筋・内転筋のピークトルク 值を測定し，トレンデレンブルグ徴候との関係について検討した。テコ比は T徵候陽性群で は術後 8 週で減少率が少なかったが，T徴候陰性群においては有意に減少していた。また， 外転筋のトルク值は $\mathrm{T}$ 徵候陽性群，陰性群間に有意差はなかったが，内転筋のトルク值は $\mathrm{T}$ 徵候陰性群に比較し, 陽性群では有意に増加していた。このことから術後のT徴候の出現に は外転筋力が最大の因子であるが，その出現には内転筋とのバランスさらにテコ比の関与も示 唆された。(リハ医学 $1999 ; 36: 234-236$ )

Key words : 人工股関節置換術 (total hip arthroplasty), トレンデレンブルグ徴候 (Trendelenburg sign)，変形性股関節症（osteoarthritis）

\section{はじめに}

人工股関節置換術 (Total Hip Arthroplasty: 以 下，THA）の術後リハビリテーションに扔いて，股 関節外転筋力の獲得は, 歩行能力の向上やインプラン トの脱臼予防などに働くため最も重要な因子の一つで ある.当科では以前より手術進入路として股関節外転 筋力が温存される Hardinge approach ${ }^{11}$ を用いてき た。また術後は徒手筋力テストにより，股関節外転筋 力を評価しながらその強化訓練を行ってきた。一般に 外転筋力の低下は，片脚起立時に下肢挙上側の骨盤が
水平位より下降するトレンデレンブルグ徴候（以下， $\mathrm{T}$ 徴候）の出現につながることが知られている.し かし, 術後に外転筋力が強いにもかかわらず $\mathrm{T}$ 徴候 の出現することはよく経験される。 T徴候の改善に は徒手筋力テストによる筋力の測定に加えて, 大腿骨 頭中心より恥骨結合中央までの距離を大腿骨頭中心よ り大転子上縁までの距離で除して得られるテコ比 ${ }^{21}$ に 代表される股関節のバイオメカニクスや股関節内外転 筋の筋出力特性の評価が必要であると思われる ${ }^{3,4)}$. 今回当科に扔いて THA を行った症例を対象として, 術前・術後の X 線像よりテコ比を計測し，また股関

1098 年 3 月 2 日受付, 1999 年 1 月 29 日受理

*1 近畿大学医学部整形外科, *2 理学療法部/ 个 589-8511 大阪府大阪狭山市大野東 377-2

Department of Orthopaedic Surgery, ${ }^{* 1}$ Department of Rehabilitation, ${ }^{* 2}$ Kinki University School of Medicine 
節外転筋・内転筋の筋機能を測定し, $\mathrm{T}$ 徵候との関 係について検討したので報告する。

\section{対象}

当科にて THA を施行した 24 例（男：1例，女： 23 例）を対象とした。原因疾患は全例変形性股関節 症で，片側性は 10 例で両側性は 14 例であった。年齢 は平均 59 歳 (44 86 歳), 平均身長は $151 \mathrm{~cm}$ $(138 \sim 162 \mathrm{~cm})$, 平均体重は $53 \mathrm{~kg}(44 \sim 65 \mathrm{~kg})$, 平 均脚延長量は $5.2 \mathrm{~mm}(0 \sim 12 \mathrm{~mm})$ であり, 使用機 種は全て Omniflex であった。股関節進入路は大転子 を切離せず, 中殿筋の後方部分を残す Hardinge approach を全例に用いた。後療法は 3 日目より Passive ROM EX を開始させ，2 週目より Active ROM $\mathrm{EX}$ ，腹臥位を開始し，4 週目より $1 / 3$ 荷重歩行（平 行棒内歩行), 6 週目より $2 / 3$ 荷重歩行 (片松葉杖歩 行）を開始し，漸次ロフストランド杖， $\mathrm{T}$ 字杖歩行 を行った.

$\mathrm{T}$ 徵候の判定は全例同一検者が両側の腸骨稜を触 診しながら， 5 秒間の片脚起立を行わせ，下肢挙上側 の腸骨稜が水平位より下降する状態を陽性とした。

\section{方法}

股関節 $\mathrm{X}$ 線前後像よりテコ比を求めた。二ノ宮 ${ }^{21}$ らの報告に準じて, 大腿骨頭中心より恥骨結合中央ま での距離 $(A)$ と, 大腿骨頭中心より大転子上縁まで の距離 $(B)$ の比をテコ比 $(A / B)$ として計測した.

股関節筋力は, 術後 8 週において体幹の固定が容易 な患側を上にした側臥位で骨盤を徒手にて固定し，等 速運動機器（川崎重工社製, MYORET RZ-450) を 使用して測定した。軸芯を大転子上内方（大腿骨頭中 心）に設定し，レバーアーム長を $33 \mathrm{~cm}$ に統一して 重力補正を行った. 角速度は $30 \% \mathrm{sec}$ で開始肢位の内 転 $10^{\circ}$ から外転 $10^{\circ}$ までの計 $20^{\circ}$ の運動範囲において, 3 回の予備試行後, 5 回最大努力を行わせ, ピークト ルク值を, 外転筋・内転筋に分けて計測して平均値を 求めた。

\section{結果}

術後 8 週で $\mathrm{T}$ 徴候陽性が 13 例に認められ, これを 陽性群とした。 T徵候の認められない 11 例を陰性群 とした。 T徵候陽性および陰性群の間に, 年齢, 身 長, 体重, THAによる脚延長量に差はなかった。し
表 1 股関節のテコ比 $(A / B)$

\begin{tabular}{ccc}
\hline $\mathrm{T}$ 徴候 & 陽性 & 陰性 \\
\hline 術前 & $2.56 \pm 0.39$ & $2.41 \pm 0.31$ \\
術後 & $2.23 \pm 0.22$ & $1.94 \pm 0.18]_{*}$ \\
\hline
\end{tabular}

$*: p<0.01$

$\mathrm{X}$ 線前後像より THA 術前・術後の股関節テコ比を計 算した。 $A$ : 大腿骨頭中心ょり恥骨結合中央までの距 離, $B$ : 大腿骨頭中心より大転子上縁までの距離

表 2 筋機能の評価

\begin{tabular}{|c|c|c|c|}
\hline $\mathrm{T}$ 徵候 & & 陽性 & 陰性 \\
\hline トルク值 & 外転筋 & $2.38 \pm 0.59$ & $2.58 \pm 0.94$ \\
\hline$(\mathrm{kg} \cdot \mathrm{m})$ & 内転筋 & $4.43 \pm 0.78$ & * $3.52 \pm 0.75$ \\
\hline
\end{tabular}

$*: p<0.01$

等速運動機器 (MYORET RZ-450) を使用して外転筋・ 内転筋のトルク值を求めた。

かし股関節テコ比は, $\mathrm{T}$ 徵候陰性群で術前 $2.41 \pm 0.31$ から術後 $1.94 \pm 0.18$ と術前より有意に減 少していたが, T 徵候陽性群では陰性群と比較して 減少率が少なかった（表 1). MYORET を使用した 筋力評価では, $\mathrm{T}$ 徵候陽性群, 陰性群間に外転筋の トルク值に有意差はなかったが, 内転筋のトルク值は $\mathrm{T}$ 徵候陰性群に比較し, 陽性群では有意に増加して いた（表 2).つぎに，T 徴候出現にどの因子が関与 するかを検討することを目的に，先に述べた 3 指標に 加えて個体差をなくすために Body Mass Index 值 $\left(\mathrm{kg} / \mathrm{m}^{2}\right)$ を加えた 4 指標を用いて判別分析を行った. 外転筋のトルク値とテコ比のみでは, $\mathrm{T}$ 徵候陽性例 を判別することはできなかった. しかし, 内転筋を含 めて線形判別関数を求めると, $Y=-1.0 X_{1}+1.7 X_{2}$ $+6.8 X_{3}-0.4 X_{4}-9.8$ の数式で表現された.ここで, $X_{1}$ は外転筋のトルク值, $X_{2}$ は内転筋のトルク值, $X_{3}$ はテコ比, $X_{4}$ は Body Mass Index 值を示す. 個々の症例の 4 指標をこの数式に代入すると, T徵 候陽性例では正の值を, 逆に $\mathrm{T}$ 徵候陰性例では負の 值をほぼ示し， 24 例中 21 例 $(88 \%)$ で判別が可能で あった。このことから術後の $\mathrm{T}$ 徴候の出現には外転 筋力以外に, テコ比抢よび内転筋の関与も示唆され た。

\section{考察}

人工股関節置換術後の股関節外転筋力の低下の原因 として罹病期間, 患者の意欲, リハビリテーション等 によるものが考えられる. それ以外にも進入路の選択 
も股関節外転筋への侵襲を考える上で重要である. 股 関節外側進入路にはいくつかの方法があり, 特に大転 子を切離する Charnley approach では, 術後大転子 偽関節などの合併症も少なくなく, Baker ${ }^{5)} ら は$ 術後 $28 \%$ の症例に外転筋力低下による $\mathrm{T}$ 徵候が認められ たと報告している。この点大転子を骨切りしない Hardinge approach は有利である. 中殿筋の後方腱 様部分は残しているため, 術後早期運動による中殿筋 の縫合不全もなく, 手術時間も短縮されるうえに出血 量も少ないため, 当科でも 1982 年 9 月以降, 人工関 節置換術以外に, 大腿骨頭を温存するカップ関節形成 術にも主としてこの進入路を用いている6).

一般に $\mathrm{T}$ 徵候には, 外転筋力の関与が主に知られ ているが, 特に外転筋の筋パワー, すなわち瞬発力が 大きく関与していることが報告されている7). しかし これのみでは $\mathrm{T}$ 徵候を予測することはできない.今 回の検討により, $\mathrm{T}$ 徵候陽性群では, $\mathrm{T}$ 徵候陰性群 に比較して内転筋のトルク值が有意に増加しており, $\mathrm{T}$ 徵候の出現には内転筋力の増加が関与することが 示唆された.さらに, $\mathrm{T}$ 徵候陰性群では股関節テコ 比は術前と比較して, 術後減少しており, これは股関 節が健常な状態に近づき, より求心性が得られたため と考元られた。 寺田8) らは片側性変形性股関節症患者 10 例の THA 術前後のテコ比を計測し, テコ比が術 前よりも小さく健側值に近似した症例では $\mathrm{T}$ 徵候陰 性となることについて報告している，以上のことから T徵候出現において外転筋力は重要な因子であるが, その出現には内転筋とのバランス, さらにテコ比も関 与していることが明らかになった。

坂本 ${ }^{9)}$ らは変形性股関節症例 121 股を検討し, 股外 転筋力值は, 進行期, 末期と関節症が進行するに従 い，有意に低下すると報告している．そのため術後の みならず術前のリハビリテーションがより重要である と考光られる.さらに術後, 歩行および片脚起立時に
下 徵候を呈する場合，骨盤の傾斜により骨頭と臼蓋 の適合性は不良となり，機能的臼蓋形成不全となる。 そして骨盤の傾斜を脊柱で矯正しょうとして, 変形性 脊椎症に,さらには膝関節荷重軸も外側に偏位し変形 性膝関節症に陥りやすくなる ${ }^{10)}$.このようなことを防 ぐために，杖の継続的な使用を勧めることが重要であ ると考えられる。

\section{文献}

1）田中清介: 下肢関節の進入路. 関節外科 $1983 ; 2$ : 124-127

2）二ノ宮節夫, 田川 宏, 宮永 豊, 関 直樹：人工股関 節の骨頭位と骨頭にかかる合力について，日整会誌 $1976 ; \mathbf{5 0}: \mathbf{1 5}-20$

3) Pai VS, D'Ortho, Ortho MS, Ortho MCh: Significance of the Trendelenburg test in total hip arthroplasty. Influence of lateral approaches. J Arthroplasty $1996 ; 11$ : 174-179

4) Horstmann T, Martini F, Knak J, Mayer F, Sell S, Zacher J, Kusswetter W : Isokinetic force-velocity curve in patients following implantation of an individual total hip prosthesis. Int J Sports Med 1994; 15: S64-S69

5) Baker AS, Bitounis VC: Abductor function after total hip replacement. J Bone Joint Surg 1989; 71B : $47-50$

6）田中清介, 福田宽二：変形性股関節症 病態・診断・治 療. メジカルビュー社, 東京, 1997 ; pp 127-147

7）福田寬二, 寺田勝彦, 辻本晴俊, 菊池 啓, 田中清介：人 工股関節置換術後にお抒け Trendelenburg 徴候. 日整 会誌 $1996 ; 70:$ S 738

8）寺田勝彦, 池川真由美, 辻 千春, 高鶴比佐志, 謝花芳 治, 中島君野, 武田芳夫, 田中清介：片側性変形性股関 節症の術前・術後のテコ比扔よび股外転筋々力と Trendelenburg 徵候との関係について. 理学療法学 $1989 ; \mathbf{1 6}: 203$ (抄)

9）坂本年将，三枝康宏：股関節外転力低下に及浔す加齢 と股関節症の影響に対する一考察. PT ジャーナル $1994 ; 28: 351-352$

10）浅田莞爾 : 変形性股関節症の力学的考察. バイオメカ ニクスよりみた整形外科（島津 晃編）. 金原出版, 東京, 1988; pp 186-192 